\title{
Getting Technical: Farmers' New Strategies to Exercise Agency in Negotiating Development Projects in Morocco
}

\author{
Nicolas Faysse ${ }^{a}$, Louisanne Thomas ${ }^{b}$ \\ a Cirad, G-Eau Research Unit, Montpellier, \\ France and Ecole Nationale d'Agriculture de \\ Meknès, Meknès, Morocco. ${ }^{b}$ Direction of Food, \\ Agriculture and Forest for the Bourgogne Region, \\ Dijon, France
}

This is the post-peer reviewed version of the article with the same title, which has been published in final form in the Forum for Development Studies at http://www.tandfonline.com/doi/abs/10.1080/08039410.2015.1094509

\begin{abstract}
Moroccan agricultural policies have not encouraged farmer participation in the design of development projects. However, changes are underway in Moroccan rural society, involving democratic opening and higher literacy rates. The present study analysed how farmers exercised agency in the design of two projects for the production and marketing of apples. These farmers had limited patronage networks to provide leverage on the main actor involved in decision-making, but their leaders had a good level of education. Farmers actively negotiated the characteristics of the projects, especially by making counter proposals that took public actors' objectives and constraints into account. For negotiations at higher levels, they formed coalitions with the local administration. Key characteristics of the projects were modified according to farmers' proposals. This way of exercising agency is innovative in the sense that it is not based on claiming rights or on cultivating relations with influential figures.
\end{abstract}

Key words: agency; development projects; farmers’ strategies; negotiation; Morocco

\section{Introduction}

In Morocco, from independence until today, the design of policies for agricultural and rural development has always been top down. After independence, one major objective of agricultural policies was to secure political support, as farmers were considered as 'pillars of the Throne' (Leveau, 1985). However, apart from the local notability (Desrues, 2006), the farmers had no voice in the design of development projects. As an alternative, they attempted to circumvent the state (Préfol, 1986) or to use adaptive strategies once the projects were being implemented. From the mid-1990s to the mid-2000s, the role of the state as the core actor of agricultural development decreased considerably, and during this period, the majority 
of farmers had very limited contacts with staff of the Department of Agriculture (Errahj et al., 2009). In 2008, an ambitious agricultural development plan, the Green Morocco Plan, was launched (Akesbi, 2012). The policy is being implemented in the presence of a democratic opening process (Sater, 2010). The aim of the Green Morocco Plan is to increase agricultural production and gives much less importance to securing political support. On the other hand, the policy is in line with past agricultural policies in that farmers' participation in the design of development projects is not explicitly expressed in the initial policy documents.

Similar situations in which farmers have weak decision-making rights in project design can be found in other developing countries. This may be because participation is not a key word in project design procedures. But since international donors now require participatory processes, today, participatory approaches are usually only absent in projects designed, funded, and implemented by national governments (Nkhoma, 2011; Veldwisch and Mollinga, 2013). Such non-participatory situations may be the result of a state with an authoritarian history, or because the state has provided limited formal space for citizens to have a say in their relations with the administration (Hossain, 2010). Farmers' decision-making rights may also be weak because participation is limited to consultations whose aim is only to gather information (Cooke and Kothari, 2001; Li, 2007).

In the case of weak decision-making rights in project design, Robins et al. (2008) consider that poor communities attempt to exercise agency by adopting two main strategies, each based on a specific context or resource. In the first strategy, people act openly and aim to be acknowledged as fully-fledged citizens. This requires the existence of patterns of governance at national level that grant rights to citizens (Gaventa, 2004). In the second strategy, people avoid the spotlight and act outside the official design procedure by exploiting patronage relationships with powerful actors (Williams et al., 2003).

In Morocco today, national agricultural and rural development policies do not grant strong decision-making rights to farmers in the design of development projects, and, in many cases, farmers have no patronage relations with powerful actors (Faysse et al., 2010; Montanari and Bergh, 2014). However, in the last decade, rural society has undergone major changes. Adult illiteracy rate decreased from 43\% in 2004 to around 30\% in 2012 (Moroccan Department of National Education and Professional Training, 2012). Moreover, farmers have gained experience in the management of producer organisations and an increasing number of leaders have a high level of formal education (Kadiri et al., 2011; Tozy, 2010).

This article analyses strategies used by farmers to influence the design of a development project in a situation where farmers had weak decision-making rights and limited access to patronage relations. The analysis focuses on two projects to plant apple trees and to build a cold storage unit in Morocco. We show that the farmers involved in these projects found a way to exercise agency, especially thanks to the formal education of their leaders and to the experience they had acquired in interactions with development organisations. This can be considered as a third strategy, in addition to the strategy of claiming rights and of exploiting patronage relations.

The article proceeds as follows. First, we present the framework we used to analyse farmers' strategies to exercise agency in the design of development projects and we use it to build a typology of farmers' strategies identified in previous studies. In section 3 , we discuss the evolution of farmers' interactions with agricultural and rural policies in Morocco. In section 4, we describe the method we used and the two case studies. In the following sections, we report and discuss the results. 


\section{Farmers' strategies in the design of development projects}

According to Chandler's (1962, p. 13) classical definition, a strategy is 'the determination of the basic long-term goals [...], and the adoption of courses of action and the allocation of resources necessary for carrying out these goals'. Based on this definition, here we consider a farmers' strategy as comprising: (i) a definition of their goals; (ii) the set of actions they decide to undertake to achieve them; and (iii) their assessment of the context in which they evolve and the resources to which they have access in that context. A strategy of this kind can help farmers exercise agency, in other words, acquire the 'capability of the individual to "make a difference" to a pre-existing state of affairs or course of events' (Giddens, 1984, p. 14). Farmers may choose their goals, actions, and the resources they use from a long-term perspective based on a careful assessment of their situation. Alternatively, farmers may take short-term decisions either because they have to face unforeseen threats or crises, or because an unexpected opportunity arises. In this case, the farmers do not choose a set strategy at the beginning of the design process, but continuously review and adapt their strategy as they go along.

The goals farmers define during the design of a development project can be positioned along two dimensions. First, farmers may aim to actively participate in the project design and act from within the official procedure, or, conversely, they may try to avoid or circumvent this procedure. Second, farmers may attempt to promote their own projects during the design process, or conversely, may try to make the best of a project whose design reflects the donor's priorities (or what the farmers believe to be the donor's priorities). Figure 1 depicts actions farmers may undertake, based on how their goals are positioned along these two dimensions. In the bottom-left quadrant of the graph, the farmers' action may be 'subversive', for example, ignoring the process or 'dragging their feet' (Scott, 1985). In this case, they may not show up at meetings organised for participatory rural appraisals. In the top-left quadrant, farmers may circumvent the official project design. Xiaoyun and Xiaoqian (2010) reported a case in which villagers called on a regional leader to confirm a project they had designed, which was threatened by their village leaders. Farmers may also call on their patrons to exercise influence on project choices (Le Meur, 2000). Masaki (2010) reported a case in which marginal farmers refused to participate in the official decision-making but used the fact that they were needed for project implementation to renegotiate their relation with the local actors who dominated the process. In the bottom-right quadrant, farmers may agree to be involved in the design process even though they know that they will have a very limited voice in decision making simply because it may be too dangerous for them to refuse (Xiaoyun and Xiaoqian, 2010). Finally, in the top-right quadrant, farmers may attempt to promote their own projects within the - often participatory - procedure of project design. Farmers with strong decision-making rights will generally apply strategies that are situated in the upper half of Figure 1.

The range of actions farmers choose to implement strategies varies in scope. Xiaoyun and Xiaoqian (2010) describe a situation in which farmers had very limited room for manoeuvre, as it would have been risky for them to confront the administration. Robins et al. (2008) consider that poor people often claim rights and cultivate relations with influential people at the same time. Funder (2010) reports a case in which farmers' strategies covered the whole range of actions in all four quadrants in Figure 1, including expressing their disagreement in the frame of the design process, making subtle changes to the project originally proposed by development organisations, and getting involved as active members in the design process. 
Moreover, the group of beneficiaries should not be considered as a homogeneous group, since the farmers involved in a development project may push for differing strategies depending on their own individual projects (Benjaminsen, 2014).

Figure 1. Typology of actions taken by farmers as a function of their goals with regards to the design process and content of development projects

$\begin{aligned} & \text { Farmers bypass the } \\ & \text { process }\end{aligned}$
$\begin{aligned} & \text { Farmers openly refuse to } \\ & \text { participate in the design } \\ & \text { process and negotiate in other } \\ & \text { arenas }\end{aligned}$

Next, we review the role of the context and of farmers' resources in the way farmers assess their room for manoeuvre and define their strategy. The context (that is, the structure as defined by Giddens, 1984) comprises both a national and a local level. When there is strong recognition of citizen rights at the national level, farmers may claim their rights to be fullyfledged partners in decision making at the project design stage: most of their actions will then be situated in the top-right quadrant in Figure 1. For instance, Beazley (2009) argued that the Indian state could no longer implement a project (in the case cited, building a dam) without the consent of the rural inhabitants. The inhabitants knew this and acted accordingly. However, when no importance is given to citizen rights at national level, poor rural inhabitants may find it more effective to adopt 'discreet patterns of agency' (Funder et al., 2012) in which case their actions will be situated in the three other quadrants.

At the local level, a key element is to what extent participatory approaches are used and actually improve farmers' capability to achieve their own goals. At the beginning of the 2000s, many authors (for example, Cooke and Kothari, 2001) gave a dismal account of farmers' actual agency in participatory processes. Participatory methods were sometimes used to give the impression the content of development projects had originated at meetings with villagers, whereas in fact, the decisions had been made in advance (Rossi, 2006). Farmers do adapt to participatory processes which do not give them a genuine role in decision making by choosing strategies situated in the bottom half and in the top-left quadrant in Figure 1. But, even when participatory approaches genuinely attempt to give farmers a say in decision making, farmers' strategies may not necessarily be situated in the top-right quadrant. Farmers 
may consider that, to secure resources, accepting what they perceive to be the donor's project is safer than pushing their own ideas. At participatory rural appraisal meetings, they may express ideas which are congruent with what they think the donors will fund (Mosse, 2005, p. 117).

Farmers' resources first comprise their ability to understand development organisations. In India, participatory policies helped rural inhabitants 'see the state' (Corbridge et al., 2005). Farmers' involvement in development projects may enable them to acquire a detailed understanding of the motives and strategies of the staff of development organisations (Funder, 2010). This enhanced understanding helps farmers choose their strategy in a much more informed way. Second, farmers may exercise agency thanks to their political capabilities (Whitehead and Gray-Molina, 1999), their brokering capacities (Bierschenk et al., 2000, p. 26-27), which include speaking 'development' language, and their ability to make their villages visible and legible to public administrations (Walker, 2012). These resources may help farmers undertake actions situated in the top-right quadrant of Figure 1. Third, farmers' resources may include belonging to social networks which extend beyond local development brokers and administration staff - in other words, the ability to not only depend on a local 'gate keeper' (Le Meur, 2000, p. 193; Xiaoyun and Xiaoqian, 2010). This will allow them to 'bypass' the official design process by undertaking actions situated in the top-left quadrant of Figure 1. All these resources may help farmers build popular (Cornwall, 2002) or 'organic' (Mansuri and Rao, 2012) capacities to play an active role in the design and implementation of public policies.

\section{Farmers' interactions with agricultural and rural policies in Morocco}

From independence to the 2000s, development actions designed by Moroccan governments have rarely 'matched' projects that were desired or initiated by farmers, either individually or collectively (Errahj et al., 2009). The state created large-scale irrigation schemes without asking farmers for their consent (Swearingen, 1987). Some farmers have demonstrated their ability to actively link up with the administration, even in regions where the state had organised strictly top-down management of agricultural activities. However, their aim was mostly to obtain access to the resources (for example, agricultural inputs, credits) the state made available based on its own policies, but which the farmers later used to implement their own projects (Bouzidi, 2012). This relationship was often informal, based on relations with influential people or in the framework of 'bricolage' with staff from the local offices of the Department of Agriculture and Fisheries (hereafter referred to as DoA). These actions are situated in the left half and in the bottom-right quadrant of Figure 1, but not in the top-right quadrant.

The first agricultural policy which acknowledged the primary importance of the concept of farmer participation was the creation of water user associations in the 1990s. Water user associations were established in both large-scale and small-scale irrigation schemes (the latter were already managed by local communities). However, in large-scale irrigation schemes, the creation of water user associations produced very limited results (Faysse et al., 2010). The lukewarm results of this policy contributed to the narrative held by many DoA staff, that farmers are not able or ready to play an active role in the institutions responsible for managing agricultural development (Faysse et al., 2012). Today, farmers are still mainly considered as beneficiaries of the actions undertaken by the DoA rather than as partners in decision making in large-scale irrigation schemes (Faysse et al., 2010). Even in recent agricultural 
development projects designed with the intention of being participatory, in practice, there may be limited empowerment of rural inhabitants (Montanari and Bergh, 2014).

In 1999, the 2020 Rural Development Strategy was enacted to eliminate rural poverty by 2020. This strategy underlined the importance of the participation of rural inhabitants and called for their involvement in the design and implementation of development actions (Department of Agriculture, Rural Development and Fisheries, 1999, p. 181). Their involvement was to take place in the frame of contractual relationships between the state and farmers' organisations. However, the strategy was never applied. In 2005, the National Initiative for Human Development was launched and also called for the participation of beneficiaries. In the framework of this policy, which was still being implemented in 2014, associations can propose social or economic development projects that may then be funded by the policy (Sater, 2010). This policy led to the 'mushrooming' of civil society organisations. However, the policy, which is managed by the Department of the Interior, has also increased the influence of the state over these local organisations (Bergh, 2012).

In contrast to the National Initiative for Human Development, the Green Morocco Plan gives much less importance to influencing the social dynamics of rural areas. The Green Morocco Plan does not mention farmers' participation in the design of the agricultural development projects it will fund, either in the main policy documents or in the original guidelines for the design of such projects. The plan considers two types of development projects: First Pillar projects focus on modern productive agriculture, while Second Pillar projects focus on so-called 'solidarity agriculture' with the aim of increasing the income of small-scale farmers. The state will finance approximately 90 per cent of the required investments in Second Pillar projects, and the farmers pay the rest. According to Akesbi (2012), the Green Morocco Plan is associated with increased forms of centralised and opaque decision making and has not set up accountability procedures to the benefit of farmers involved in Second Pillar projects. Even though farmers' participation was not formally mentioned in the first policy documents, in practice, beneficiaries are required to create cooperatives or associations to coordinate with DoA offices.

Many farmers' organisations were established by the state in the 1970s and the 1980s, but in the meantime, the state handed over their control to local elites. The main resources of these notables were their patronage networks (Leveau, 1985) and they had often limited formal education (Tozy, 2010). From the 1990s on, the reduced influence of the state in the governance of these organisations paved the way for the re-appropriation of the organisations by their members. In the last two decades, farmers have gained experience in cooperative action within the framework of farmers' organisations (Faysse et al., 2010). New forms of leadership have appeared at the local level (Benidir, 2011). Young farmers have higher levels of formal education and there is an increasing number of young educated leaders whose legitimacy is based on their skill in participating in the design and implementation of public actions (Kadiri et al., 2011; Tozy, 2010). However, small-scale farmers have only gained control over farmers' organisations at local level. They have no control over larger farmers' organisations at regional level (for example, Chambers of Agriculture), which are still managed by the traditional elite (Faysse et al., 2010). Moroccan small-scale farmers have little political strength in their own right, and in particular, no unions. 


\section{Case Studies: Agricultural background and research method}

The two development projects described here took place in Sefrou province (northern Morocco). The projects were selected because: (i) they were among the first designed in the framework of the Green Morocco Plan in this province, (ii) they both concerned apples, a major agricultural product in Sefrou province, and (iii) they had very similar features, involving the building of a cold storage unit and planting apple orchards. The aim of both projects was to increase the quantity and improve the quality of apples and to improve marketability. At the time of the study (2013), the design of both projects was complete. The cold storage unit belonging to cooperative A was under construction, whereas cooperative B had not yet signed the final agreement.

Here we give only the information needed to understand the negotiations concerning the design of the two projects. In Sefrou province, the apple value chain is informal and includes many intermediaries. The intermediaries often have a stronger bargaining position than farmers during the harvest period, because unless the apples are put into cold storage, their quality deteriorates in the first three weeks after harvest. In Sefrou province, apples are produced in two main ways. Traditionally, the density of the orchards was low (around 625 trees per ha). New orchards increasingly have a high density (1,200 - 1,600 trees per ha). The newer orchards produce much higher yields, and treatment and harvesting is much easier as the trees are planted in rows, with ample space for the passage of farm machinery. As this new technique is expensive, only a few small-scale farmers can afford to invest in highdensity orchards. In addition, in Morocco, certified apple trees are not yet produced. The only way to obtain certified apple trees is to import them from Europe, which is very expensive for small-scale farmers, who consequently buy and plant local trees. The most commonly cultivated variety in Morocco is Golden Delicious, but Gala was introduced on large-scale farms a few years ago. As Gala is an earlier variety than Golden Delicious, the sales price is approximately $50 \%$ higher.

The method used in the present study unravelled the 'entangled social logic approaches to development' described by Olivier de Sardan (2005) particularly by analysing farmers' agency through a detailed assessment of the different proposals and counter-proposals put forward during negotiations on the design of the project. Interviews were conducted with 18 farmers in each of the two case studies (chosen as representative of the range of farm sizes in each cooperative). All the interviewees were men, as were all members of both cooperatives. We also interviewed seven members of the management committees of the two cooperatives involved in the projects, and seven staff members of all the DoA offices involved in project design. Following Bierschenk (1988), the study started with the analysis of the original goals each of the actors had for the project. Particular attention was paid to the occasions on which some of these actors expressed disagreement with the content of the project, the kind of initiatives each of these actors took on those occasions, and the impacts of actors' strategies and interactions on the project design. The interviews were conducted between October 2012 and February 2013 and follow-up continued until summer 2014.

\section{Results}

\section{Main actors involved in the design of the projects}

A cooperative was created in both case studies (hereafter referred to as cooperatives A and B). In both cooperatives, members had similarly sized farms, in cooperative A, between 5 and 10 
ha, half of which planted with apple or plump trees. In Cooperative B, the members' farms ranged from 2 to 10 ha, and were mostly planted with apple trees. Growing fruit trees helped these farms obtain a much higher income than most farms of similar size in Morocco. However, the farms were small compared to several large-scale farms in the vicinity of the two cooperatives, which each had at least 70 ha of apple orchards.

Cooperative A was created in 2005. In the village where members of cooperative A lived, several associations had been involved in village activities since 1999, including youth employment, education, and access to drinkable water. The cooperative sold milk and in 2012, had benefitted from a project to dry plums funded by the DoA. In 2011, members of cooperative A accused the then president of the cooperative of corruption and held an extraordinary general meeting to elect a new president. The cooperative employee was also accused of corruption and fired. The newly elected management committee were not members of the local notability (farmers who owned the largest farms in the vicinity were not members of the cooperative). The size of the farms belonging to the leaders of the cooperative was in the average range of those belonging to the other members. The management committee included two key leaders with a high level of formal education: a teacher, who was a university graduate, and the mayor of the rural municipality where cooperative A was located, who was an engineer and worked in Fes, the capital of the region, during the week. The mayor was elected as a member of the management committee because of his professional skills, and did not come from a historically powerful family. The legitimacy the leaders of the two cooperatives enjoyed was based on their ability to organise collective action. As one member told us: 'the mayor has worked a lot for the cooperative, he does not intend to let it disappear and keeps coming up with new projects'. Accountability was a high priority in cooperative A: members actively pressured leaders to justify their choices and, at the annual general meetings, required detailed reports on the results of the actions of the leaders. The administration considered this cooperative to be exemplary in Sefrou province. In 2012, cooperative A had 108 members.

Cooperative B was more recent. In 2009, three farmers decided to create an informal group for the joint purchase of agricultural inputs. In 2011, the group had nearly 30 members who were members of the families of the three leaders or friends of the leaders. However, at the beginning, the group did not pursue any particular activity, mainly due to lack of funding. In 2011, the group registered the cooperative to be able to benefit from public funding. Among the three leaders, the president of the cooperative had a BSc in chemistry, and his brother had a BSc in agriculture. None of Cooperative B members had participated in a development project involving public subsidies.

Different DoA offices were involved in the design of the two projects. The Agricultural Development Agency (ADA) was created in 2009 to fund and monitor all development projects designed in the framework of the Green Morocco Plan. The headquarters of the ADA are in Rabat, the Moroccan capital. The ADA is at the top of the hierarchy in the decisionmaking process for the design of Green Morocco Plan projects. It evaluates the projects at several stages in the design process, and may oblige the local offices of the DoA to modify the project design. At the outset of the Green Morocco Plan, the regional DoA offices set out the main objectives in terms of increases in production per year. Each region has several provinces, each of which has a DoA provincial office. The most decentralised units are the socalled 'Work Centres', which are mainly responsible for agricultural extension. Concerning the two projects described here, the Fes-Boulemane regional office of the DoA originally 
began coordinating project design, but in 2010, the Sefrou provincial office of the DoA took over coordination between all the actors involved. Private firms contracted by the provincial DoA offices were in charge of implementing the projects per se (for example, building the cold storage unit).

\section{Initial goals of the actors for the projects}

In both cooperatives, the farmers we interviewed told us the marketing of apples was a major problem. Most were interested in keeping their products in cold storage, but could not, either because they could not afford to (the farmers had to pay for cold storage in privately owned units at harvest) or because, in good harvest years, there was not enough room in existing cold storage units in the region. Even before the creation of the Green Morocco Plan, the two cooperatives had wanted to build a cold storage unit so their members could store part of their harvest. This would also provide the cooperatives with income, in the same way as the privately owned units. However, neither of the cooperatives had the financial means to purchase a cold storage unit (a 1,000 ton unit costs approximately 450,000 euros). The two cooperatives also wanted to take more initiative in the longer term, such as joint marketing of apples produced by the members of the cooperative.

Farmers in the two cooperatives were also interested in the plantation component of the projects. However, they considered it much less important than acquiring a cold storage unit, because they did not need outsider help to plant trees. The farmers' aim was to obtain higher yields at less cost thanks to new varieties and improved technology. They wanted to have access to the technology used by large-scale farms with minimum personal investment. They consequently applied for imported Gala trees, to be planted at a high density to make mechanised treatment possible.

As the aim of the Green Morocco Plan was to achieve major increases in agricultural production, a key indicator of success for all offices of the DoA was the surface area planted with apple trees. In addition, the ADA wanted to have a large number of beneficiaries, and consequently made sure that the ratio of the total cost of the project to the number of beneficiaries was not too high. The Sefrou provincial office of the DoA shared these objectives and also considered that the two Green Morocco Plan projects described here provided an opportunity to create active groups of farmers who could later be involved in other projects. The provincial office also wanted farmers' groups to actively participate both in project design and funding to confirm their sense of ownership of the projects. For these reasons, they thought the farmers themselves should purchase the land on which the cold storage unit was to be built.

In the following subsections, we analyse the two design processes with a focus on the key moments in the negotiations. Table 1 shows the position of each actor with respect to the main components of the projects which initially involved a difference in opinion among the main actors, along with the final characteristics of these components. 
Table 1. Position of each actor with respect to the main components of the project which were the subject of negotiation, and their final characteristics

\begin{tabular}{lll}
\hline $\begin{array}{l}\text { Coopera- } \\
\text { tive }\end{array}$ & $\begin{array}{l}\text { Main components of Characteristics } \\
\text { the project that were sought by ADA } \\
\text { negotiated }\end{array}$ & $\begin{array}{l}\text { Characteristics Characteristics Final characteristics } \\
\text { sough by the sought by the } \\
\text { provincial office cooperative } \\
\text { of the DoA }\end{array}$
\end{tabular}

\begin{tabular}{|c|c|c|c|c|c|}
\hline \multirow[t]{5}{*}{$\begin{array}{l}\text { Coopera- } \\
\text { tive A }\end{array}$} & Plantation component & $\begin{array}{l}\text { Financed by the } \\
\text { DoA }\end{array}$ & $\begin{array}{l}\text { Financed by the } \\
\text { DoA }\end{array}$ & $\begin{array}{l}\text { Financed by the } \\
\text { DoA }\end{array}$ & Financed by farmers \\
\hline & $\begin{array}{l}\text { Density of plantation } \\
\text { (trees/ha) }\end{array}$ & 625 & 1,600 & 1,600 & Farmers' decisions \\
\hline & Apple variety & $\begin{array}{l}\text { At least } 2 / 3 \text { of } \\
\text { trees of Golden } \\
\text { Delicious }\end{array}$ & $\begin{array}{l}\text { Golden Delicious } \\
\text { or Gala }\end{array}$ & Gala & The farmers decided \\
\hline & Origin of trees & Local or imported & Imported & Imported & Local \\
\hline & $\begin{array}{l}\text { Equipment of the cold } \\
\text { storage unit }\end{array}$ & $\begin{array}{l}\text { Financed by } \\
\text { farmers }\end{array}$ & $\begin{array}{l}\text { Financed } \\
\text { farmers }\end{array}$ & $\begin{array}{l}\text { Financed by the } \\
\text { DoA }\end{array}$ & Financed by the DoA \\
\hline \multirow[t]{5}{*}{$\begin{array}{l}\text { Coopera- } \\
\text { tive B }\end{array}$} & $\begin{array}{ll}\text { Number } & \text { of } \\
\text { beneficiaries } & \end{array}$ & 150 & 150 & $\begin{array}{l}40 \text { for the cold } \\
\text { storage unit }\end{array}$ & $\begin{array}{l}111 \text { for the whole project } \\
\text { among whom } 38 \text { benefit } \\
\text { from the cold storage unit }\end{array}$ \\
\hline & Area planted (ha) & 300 & 300 & 100 & 100 \\
\hline & $\begin{array}{l}\text { Planting } \quad \text { density } \\
\text { (trees/ha) }\end{array}$ & 625 & 1,000 & 1,000 & $\begin{array}{l}625 \text { paid for by the project. } \\
\text { The farmers must pay to } \\
\text { increase density }\end{array}$ \\
\hline & Origin of trees & Local & Imported & Imported & Imported \\
\hline & Apple juice plant & Not included & Included & Included & Not included \\
\hline
\end{tabular}

\section{Project design process in cooperative $A$}

In 2007, the leaders of cooperative A applied to the provincial office of the DoA for funding to build a 1,000 ton cold storage unit. The leaders of the cooperative already knew the staff of the provincial office thanks to the above-mentioned milk collection project. However, at the time of the application, the provincial office of the DoA did not have sufficient funds for the new project. Later, in 2009, the mayor of the rural municipality in which cooperative A was located proposed a different project to an executive of the regional office of the DoA. This project concerned 80 hectares of land that had not previously been planted because each farmer only owned very small plots of land. The aim of the project was to group the land so that each farmer would have a single stretch to be planted with apple trees. The executive of the DoA suggested the plantation project should take place in the framework of the Green Morocco Plan, and that the cooperative should be the organisation grouping the beneficiaries. He knew that the cooperative also wanted a cold storage unit. He told the leaders of the cooperative that this was a good opportunity to start designing a project as part of the Green Morocco Plan, and that the plantation component would justify asking the ADA to later include the building of a cold storage unit in the project. The cooperative accepted the plantation project with the aim of obtaining a cold storage unit. The plantation component was designed and accepted in 2009, and the building of a 1,000 ton cold storage unit was indeed added to the project in 2010.

The apple trees were supposed to be planted in 2010. However, grouping the land failed because the owners of the 80 hectares failed to reach agreement on the land grouping process. The provincial and regional offices of the DoA were very disappointed, and the project was on the brink of being cancelled. However, the Minister of Agriculture happened to be in the region and decided that the project should go forward. The DoA offices and cooperative A 
decided to continue with the project with the same beneficiaries, but that plantation would concern other pieces of land, which were not connected to each other, but which still amounted to a total area of 80 hectares.

At the beginning of the project design process, the members of cooperative A were not aware of the details of the plantation component. The project stated a density of 625 trees per ha, which had been established by the regional office of the DoA and the ADA in 2009. This low density was chosen first to reduce the cost of the project per surface area for each beneficiary, thus enabling the DoA to fund a larger area of planted trees with the same budget. Second, the ADA argued that only large-scale farmers could successfully manage highdensity orchards. The members of cooperative A only discovered the intended low tree density when planting was due to begin, and were surprised, as they had expected a density of 1,600 trees per ha, since the imported varieties they had requested are usually planted at high densities.

The farmers who belonged to cooperative A expressed their disagreement with the proposed density. They argued that they needed to cultivate their small areas of land intensively and that they had the technical skills to manage high-density orchards. As a result, preparations for planting the apple trees stopped. The staff of the provincial DoA office, who had just taken over the coordination of the project from the regional office, already had many contacts with the farmers. Unlike the ADA, they had confidence in the farmers' technical ability and tried to renegotiate the budget with the ADA to increase the density. They also organised a meeting between the ADA and the leaders of cooperative A to try and change the ADA staff's mind. These efforts failed, and the ADA continued to refuse high-density plantation. Finally, the provincial DoA office set up an arrangement between the farmers and the firm responsible for planting. The firm would plant 1,625 trees per ha, out of which the project would finance 625 and the farmers would pay for 1,000.

A new budget was prepared in 2012, but another problem arose. Farmers wanted to plant Gala, whereas the project stipulated that two thirds of the trees should be Golden Delicious. The ADA believed that Gala were difficult to store in cold storage. The farmers finally accepted that two thirds of the trees should be Golden Delicious, but insisted on specific rootstock. The firm in charge of planting the trees argued that this would mean that the trees would have to be ordered in France two years before planting. The plantation component of the project was consequently once again delayed.

Originally, the DoA had planned to finance the full cost of the cold storage unit, including all the necessary equipment such as crates for the apples, a power transformer, and pallet trucks, while the cooperative would purchase the land on which the cold storage unit was to be built. However, the DoA later realised the project would cost more than originally planned. When construction began, the DoA announced that the equipment for the cold storage unit (worth around 65,000 euros) would have to be financed by the cooperative, but the cooperative did not have the necessary capital. The leaders of the cooperative made an appointment with the director of the ADA in Rabat, when they suggested transferring the funds originally destined for planting the apple trees to the purchase of the equipment needed for the cold storage unit. Since they realised that planting apple trees was a key indicator of success for the DoA, they promised that, in exchange, they would finance the planting of 80 hectares of apple trees themselves. In doing so, they were confident that the 80 hectares would be planted by the farmers, who were already increasing the amount of land planted with apple trees on their own. The ADA accepted the farmers' proposal. 
In 2011, the local office of the DoA contracted a company to build the cold storage unit, which was supposed to be completed by July 2012. However there were serious delays in construction. The local office of the DoA decided to look for another company but became embroiled in the contracts. Cooperative A had no formal way to intervene, as the construction contracts were between the companies and the provincial DoA office. Construction of the cold storage unit only resumed in summer 2014.

\section{Project design process in cooperative $B$}

In 2011, the staff of the provincial office of the DoA reviewed the progress of the Green Morocco Plan, and discovered that no project had been designed in the rural municipality in which cooperative B was located. Bearing cooperative A's previous experience in mind, they decided to launch an apple project. The original DoA project involved a 300-ha plantation with 150 beneficiaries, plus a 2,000 ton cold storage unit. The representatives of the few existing cooperatives in the municipality were invited to a meeting during which the staff of the DoA presented the Green Morocco Plan and explained that they were looking for cooperatives interested in participating in Second Pillar projects. Following the meeting, cooperative B presented a project for the construction of a cold storage unit to the provincial office of the DoA.

Cooperative $\mathrm{B}$ and the DoA started discussing the design of the project. The members of cooperative $B$ refused to share a 2,000 ton cold storage unit among 150 beneficiaries, arguing that this would leave very little room in the unit for each farmer, and that it was much more difficult to manage a cooperative with 150 members than one with only 30 . But the regional and provincial offices of the DoA considered that, to achieve the regional objectives of the Green Morocco Plan, they needed to have as many beneficiaries as possible in the project. The provincial office of the DoA and the cooperative then agreed on a 100-ha plantation with 111 beneficiaries. Among these beneficiaries, 38 were members of cooperative B (some farmers had recently joined the cooperative to benefit from the project) and would own and manage the cold storage unit jointly. The other 73 farmers would benefit from the plantation, but would not be members of the cooperative and would thus not become shareholders in the cold storage unit. All 38 members of the cooperative paid 1,000 euros each to collectively purchase the plot where the cold storage unit was to be built. Cooperative B also wanted to include an apple juice plant in the project. The provincial DoA office supported this proposal, but the ADA rejected it, arguing that it would be too costly and that not enough preliminary studies had been conducted.

Concerning the plantation component, the president of cooperative B did not ask for any particular conditions since the beneficiaries had different expectations. However, the cooperative wanted imported trees and requested a density of at least 1,000 trees per ha. The provincial office of the DoA agreed. When the project designed by the provincial office and the farmers was sent to ADA, the latter refused the density of 1,000 trees per ha for the same reasons as those given to cooperative $\mathrm{A}$. The ADA suggested purchasing local trees instead of imported trees, but both the provincial DoA office and the cooperative refused to plant local trees, as the orchards had to be of high quality. Farmers, the provincial DoA office, and the ADA finally agreed on planting imported Golden Delicious. The cooperative accepted that the project would fund the planting of 625 plants per ha, and that farmers who wished to increase this density would pay the difference directly to the firm responsible for planting trees. 


\section{Discussion}

\section{Farmers' strategy to promote their own project}

Here we summarize the farmers' strategy with respect to the framework presented at the beginning of the paper. Concerning the local context, the pattern of governance in the two case studies shared traits with the national pattern described above. First, the DoA offices, and particularly the ADA, had no close ties with local politicians or with the local notability concerning the design of Second Pillar projects. The cooperatives had thus limited opportunities to use patronage relations. Second, the process for the design of the two projects was not based on a discourse which included participation by the farmers. No committee existed for the design of projects in which the two cooperatives had an official decisionmaking role. However, the DoA was under strong pressure to start projects as the performance of the staff of the different DoA offices was evaluated on this basis. When cooperative A's project was on the brink of being cancelled because of the failure to group the land, the Minister of Agriculture's desire to find a solution made the leaders of the cooperative realise the DoA needed to get projects off the ground. They realised that they had some room for manoeuvre in the negotiation over project design, especially since they knew that they were recognised as the most active and experienced cooperative in the province.

Concerning the farmers' resources, the fact that one leader of cooperative A was the mayor of the municipality helped the cooperative deal with regional administration, but did not help negotiate with the ADA. Farmers' key resources were not their links with influential people. Rather, thanks to their high level of formal education, several leaders of the two cooperatives had a good understanding of the logic and constraints of public administration. Moreover, when cooperative A started interacting with the DoA on the subject of project design, it already had more than eight years' experience both in group management and in how to interact with the state administration. The farmers were familiar with the 'machinery' of the DoA, especially the role of the different administrative levels in decision making.

Based on this assessment of the context and their resources, farmers decided to push their own projects (that is, their actions were situated in the upper part of Figure 1), using a wide range of actions located in both the top-left and top-right quadrants in Figure 1. With regards to the top-left quadrant (farmers do not to participate in the design process or circumvent it), cooperative A took the initiative to get in touch with the ADA, thus bypassing the provincial and regional offices of the DoA to defend their ideas for the project directly with the actor who had the final word in the decision making.

With regards to the top-right quadrant (farmers deal with the administration within the official design procedure), first farmers made several counter-proposals to the DoA, for instance with regards to plantation density in both cooperatives and to the allocation of funds in cooperative A. Second, they formed a coalition with the provincial DoA office to improve their ability to persuade the ADA. As Table 1 shows, the position of the provincial office of the DoA was aligned with that of the farmers in both cooperatives and not with that of the ADA on several components of the projects. On several occasions, the leaders of the cooperatives acted as partners of the provincial office and gave the staff technical arguments to use in their negotiation with the ADA (for example, on plantation density). The negotiations thus often took place between farmers and the provincial office of the DoA on the one hand, and with the ADA on the other, rather than between the DoA offices and the farmers. However, there was a strong power asymmetry between the DoA offices. The ADA imposed its viewpoint in the final decision concerning the characteristics of at least one 
component of the project in each cooperative (see Table 1). Overall, farmers undertook more actions situated in the top-right quadrant than in the top-left one. Generally, farmers choose actions in the top-right quadrant when their rights are strong enough to guarantee their point of view will influence the decision-making process for project design. Farmers in cooperatives $\mathrm{A}$ and $\mathrm{B}$ opted for actions in this quadrant despite not having strong rights in the decision-making process.

\section{Getting technical: an innovative strategy to exercise agency}

Some actions undertaken by the farmers in the two case studies have already been described. For instance, the farmers' move to by-pass the local decision-making levels and make direct contact with upper levels was identified by Xiaoyun and Xiaoqian (2010). The originality here is the farmers' strategy. We referred above to Robins et al.'s (2008) analysis that farmers may choose between two main strategies: claiming rights (based on an enabling environment at national level) and making use of patronage relations (if the farmers have such relations). Here, in a situation of weak decision-making rights and lack of patronage relations able to put pressure on the key decision makers, the farmers used a third strategy, acting within the official framework and 'getting technical' by making counter-proposals that account for the goals of the development organisations. A 'getting technical' strategy first requires a specific farmers' resource: a detailed understanding not only of the goals but also of how development organisations function. Second, the institutional environment needs to be at least 'mildly open', that is, development organisations do not use a strong participatory discourse and do not officially grant farmers formal rights to participate in the decisions on project design, but are nevertheless likely to listen to and consider farmers’ proposals.

Hickey and Mohan (2004) argued that the participation of communities targeted as beneficiaries of development actions should be embedded within a broader approach that focuses on the transformation of the power relationship between the communities and development organisations and the improvement of the rights of these communities. A now well-framed argument (for instance, Cooke and Kothari, 2001) is that participation of these communities in the design of development projects will likely lead to manipulation by development organisations if the issues of power relationships and decision-making rights are not dealt with actively. In our case studies, the farmers were able to push forward their own project, even though they had no rights which would guarantee their ability to influence decision making, and even though they did not challenge power relations with development organisations. The 'getting technical' strategy thus appears to be appropriate in the current institutional context in Morocco and given the resources the farmers in the case studies had at their disposal. This does not mean that the strategy has no limits, and in fact, its limits did become apparent during the implementation of the project, when cooperative A found no way to prevent further delays in the construction of the cold storage unit. The farmers did not increase their ability to hold public organisations accountable. This lack of formal decisionmaking rights may continue to be a weakness in the future, as the DoA may unilaterally decide to pay less attention to farmers' claims and proposals.

Farmers are often portrayed in development studies (e.g. Cooke and Kothari, 2001) as being disadvantaged in their negotiations with development organisation technicians, even in participatory processes. A frequent explanation is that farmers have less ability to negotiate the details of development projects than the technicians. Rendering the design process technical may be even a tool used by the staff of development organisations to build and maintain a barrier between themselves, as experts who are able to assess and transform issues 
into concrete problems, and those who are the subject of the assessments ( $\mathrm{Li}, 2011, \mathrm{p} .7)$. This asymmetry has sometimes been considered to be so 'in-built' that proposals to empower farmers focused mainly on changing power relations and improving farmers' rights, and gave comparatively less importance to farmers' capacity-building on the technical components of the projects (for instance, Hickey and Mohan, 2004). As levels of formal education are generally increasing in rural areas in developing countries, this asymmetry between farmers and technicians of development organisations is likely to continue, but should not be considered as intrinsic.

\section{Conclusion}

In the two cooperatives described here, farmers actively negotiated the content of development projects despite the lack of a clear participatory policy. In a context of weak decision-making rights and absence of patronage networks, farmers were able to move their projects forward during the design of the project by 'getting technical', a strategy that was not one of claiming rights or based on nurturing patronage relations. This strategy was mainly based on negotiating the content of development projects by making detailed counterproposals which corresponded to the farmers' own goals but simultaneously took the objectives of the different levels of administration of the DoA into account. It also involved building coalitions with the staff of some administrations to improve their own bargaining position vis-à-vis other administrations. The farmers who belonged to the two cooperatives did not obtain everything they wanted by using this strategy, but in each case, they obtained a result of key importance for them: farmers in cooperative A managed to avoid paying for equipping the cold storage unit, and farmers in cooperative B managed to limit the number of members of their cooperative.

The two cases reported here are by no means representative of farmers' involvement in the coordination of agricultural activities in Morocco. However, they clearly signal a change. Whereas in the past, Moroccan farmers mostly adapted to state proposals or tried to circumvent the procedure (the lower part and top-left quadrant of Figure 1), in our two case studies farmers mostly acted by pushing forward their own projects within the official framework (top-right quadrant in Figure 1). This is evidence for a profound change in the relations between the Moroccan state and the farmers.

This third strategy emerged because although farmers had no decision-making rights or patronage resources, they had access to other resources. Any analysis of farmers' strategies should thus make a detailed assessment of the farmers' own resources and of the context that may make these resources available or, on the contrary, constrain them. In particular, the farmers' higher level of formal education should be recognised as a promising resource, and as a means to support 'soft ways' for farmers to exercise agency and achieve their goals, in situations of weak decision-making rights in the design of development projects.

\section{Acknowledgements}

This work was supported by the Agence Nationale de la Recherche (French National Agency for research) as part of the Groundwater Arena project. 


\section{References}

Akesbi, N., 2012, 'Une nouvelle stratégie pour l'agriculture marocaine: Le «Plan Maroc Vert »', New Medit, Vol . 2, pp. 12-23.

Beazley, K., 2009, 'Interrogating notions of the powerless oustee', Development and Change, Vol. 40, No. 2, pp. 219-248.

Benidir, M., 2011, 'Leaders associatifs et élus locaux au Maroc: Epreuves de face-à-face et controverses dans les arènes du développement', Politique Africaine, Vol. 4, No. 120, pp. 87104.

Benjaminen, G., 2014, 'Between resistance and consent: Project-village relationships when introducing REDD+ in Zanzibar’, Forum for Development Studies, Vol. 41, No. 3, pp. 377398.

Bergh, S., 2012, “'Inclusive” neoliberalism, local governance reforms and the redeployment of state power: The case of the National Initiative for Human Development (INDH) in Morocco', Mediterranean Politics, Vol. 17, No. 3, pp. 410-426.

Bierschenk, T., 1988, 'Development projects as arenas of negotiation for strategic groups: A case study from Benin’, Sociologia Ruralis, Vol. 28, No. 2-3, pp. 146-160.

Bierschenk, T., J.P. Chauveau and J.P. Olivier de Sardan, 2000, 'Introduction. Les courtiers entre développement et État,' in T. Bierschenk, J.P. Chauveau and J.P. Olivier de Sardan, eds, Courtiers en Développement: les Villages Africains en Quête de Projets, Paris : Karthala, pp. 5-42.

Bouzidi, Z., 2012, Dénouer les Fils de la Coordination à Travers l'Appréhension des Grammaires Locales. Analyse des Pratiques de Coordination pour la Gestion des Ressources Productives dans le Périmètre du Gharb au Maroc, PhD dissertation, Paris, Paris 10 University.

Chandler, A., 1962, Strategy and Structure: Chapters in the History of the Industrial Enterprise, Cambridge: MIT Press.

Cooke, B. and U. Kothari (eds), 2001, Participation: The New Tyranny? London: Zed Books. Corbridge, S., G. Williams, M. Srivastava and R. Véron (eds), 2005, Seeing the State: Governance and Governmentality in India, Cambridge: Cambridge University Press.

Cornwall, A., 2002, Making Spaces, Changing Places: Situating Participation in Development, Brighton: Institute of Development Studies, Vol.170.

Desrues, T., 2006, 'Le corporatisme agrarien au Maroc. La trajectoire de l’Union Marocaine de l’Agriculture', Revue des Mondes Musulmans et de la Méditerranée , Vol. 111-112, pp. 197-217.

Errahj, M., M. Kuper, N. Faysse and M. Djebbara, 2009, 'Finding a way to legality: Local coordination modes and public policies in large-scale irrigation schemes in Algeria and Morocco', Irrigation and Drainage, Vol. 58, No. S3, pp. 358-369.

Faysse, N., M. Errahj, C. Dumora, H. Kemmoun and M. Errahj, 2012, 'Linking research and public engagement: Weaving an alternative narrative of Moroccan family farmers' collective action', Agriculture and Human Values, Vol. 29, No. 3, pp. 413-426.

Faysse, N., M. Errahj, M. Kuper and M. Mahdi, 2010, 'Learning to voice? The evolving roles of family farmers in the coordination of large-scale irrigation schemes in Morocco’, Water Alternatives, Vol. 3, No. 1, pp. 48-67.

Funder, M., R. Bustamante, V. Cossio, P. Huong, B. van Koppen, C. Mweemba, I. Nyambe, L.T. Thanh Phuong and T. Skielbo, 2012, 'Strategies of the poorest in local water conflict and cooperation. Evidence from Vietnam, Bolivia and Zambia', Water Alternatives, Vol. 5, No. 1, pp. 20-36. 
Funder, M., 2010, 'The social shaping of participatory spaces: Evidence from community development in Southern Thailand', Journal of Development Studies, Vol. 46, No. 10, pp. 1708-1728.

Gaventa, J., 2004, 'Towards participatory governance: Assessing the transformative possibilities', in Sam Hickey, and Giles Mohan, eds, Participation - from Tyranny to Transformation? Exploring New Approaches to Participation in Development, London: Zed books, pp. 25-41.

Giddens, A., 1984, The Constitution of Society: Outline of the Theory of Structuration. Berkeley, CA: University of California Press.

Hickey, S. and G. Mohan. 'Towards participation as transformation: Critical themes and challenges', in S. Hickey and G. Mohan, eds, Participation - from Tyranny to Transformation? Exploring New Approaches to Participation in Development, London: Zed books, pp. 3-24.

Hossain, N., 2010, 'Rude accountability: Informal pressures on frontline bureaucrats in Bangladesh', Development and Change, Vol. 41, No. 5, pp. 907-928.

Kadiri, Z., M. Kuper and M. Errahj, 2011, 'Projets d'aménagement et développement territorial: le cas du périmètre irrigué du Moyen Sebou au Maroc', Pôle Sud, Vol. 2, No. 35, pp. 77-96.

Le Meur, P.Y., 2000, 'Courtage en développement et champ du pouvoir local au Sud-Bénin', In T. Bierschenk, J.P. Chauveau, and J.P. Olivier de Sardan, eds, Courtiers en Développement: les Villages Africains en Quête de Projets, Paris : Karthala, pp. 5-42.

Leveau, R., 1985, Le Fellah Marocain Défenseur du Trône, Paris : Presses de la Fondation Nationale des Sciences Politiques.

Li, T., 2007, The Will to Improve: Governmentality, Development, and the Practice of Politics, Durham: Duke University Press.

Mansuri, G. and V. Rao, 2012, Localizing Development: Does Participation Work? Washington (DC): World Bank Publications.

Masaki, K., 2010, 'Rectifying the anti-politics of citizen participation: Insights from the internal politics of a subaltern community in Nepal', Journal of Development Studies, Vol. 46, No. 7, pp. 1196-1215.

Montanari, B. and S. Bergh, 2014, "The challenges of "participatory" development in a semiauthoritarian context: The Case of an essential oil distillation project in the High Atlas Mountains of Morocco', The Journal of North African Studies, Vol. 19, No. 5, 19(5), pp. 828851.

Moroccan Department of Agriculture, Rural Development and Fisheries, 1999, Stratégie 2020 de Développement Rural. Document de Référence, Unpublished document. Rabat, Morocco.

Moroccan Department of National Education and Professional Training, 2012, Rapport National Education Pour Tous 2012, Rabat.

Mosse, D., 2005, Cultivating Development: An Ethnography of Aid Policy and Practice, London: Pluto Press.

Nkhoma, B., 2011, 'The politics, development and problems of small irrigation dams in Malawi: Experiences from Mzuzu ADD’, Water Alternatives, Vol. 4, No. 3, pp. 383-398.

Olivier de Sardan, J.P., 2005, Anthropology and Development: Understanding Contemporary Social Change, London: Zed Books.

Préfol, P., 1986, Prodiges de l'Irrigation au Maroc, le Développement Exemplaire du Tadla 1936-1985, Paris: Nouvelles Éditions Latines.

Robins, S., A. Cornwall and B. von Lieres, 2008, 'Rethinking "Citizenship" in the Postcolony’, Third World Quarterly, Vol. 29, No. 6, pp. 1069-1086. 
Rossi, B., 2006, 'Aid Policies and recipient strategies in Niger: Why donors and recipients should not be compartmentalized into separate "worlds of knowledge", in D. Lewis, and D. Mosse, eds, Development Brokers and Translators: The Ethnography of Aid and Agencies, Bloomfield, CT: Kumarian Press, pp. 27-49.

Sater, J., 2010, Morocco: Challenges to Tradition and Modernity, Oxon: Routledge.

Scott, J., 1985, Weapons of the Weak: Everyday Forms of Peasant Resistance, New Haven: Yale University Press.

Swearingen, W., 1987, Moroccan Mirages: Agrarian Dreams and Deceptions 1912-1986, Princeton: University Press.

Tozy, M., 2010, 'Leaders et leadership. configurations complexes, ressources politiques et influence potentielle des leaders dans le cas de l'oriental marocain', in P. Bonte, M. Elloumi, H. Guillaume and M. Mahdi, Développement Rural, Environnement et Enjeux Territoriaux : Regards Croisés Oriental marocain et Sud-Est tunisien, Rabat : La Croisée des Chemins, pp. 363-378.

Veldwisch, G. and P. Mollinga, 2013, 'Lost in transition? The introduction of water users associations in Uzbekistan’, Water International, Vol. 38, No. 6, pp. 758-773.

Walker, A., 2012, Thailand's political peasants. Power in the Modern Rural Economy, Madison, Wisconsin, USA: University of Wisconsin Press.

Whitehead, L. and G. Gray-Molina, 2003, 'The long-term politics of pro-poor policies', in P. Houtzager, and M. Moor, eds, Changing Paths: International Development and the New Politics of Inclusion, Ann Arbor, MI: University of Michigan Press, pp. 32-57.

Williams, G., R. Veron, S. Corbridge and M. Srivastava, 2003, 'Participation and power: Poor people's engagement with India's Employment assurance scheme’, Development and Change, Vol. 34, No. 1, pp. 163-192.

Xiaoyun, L. and L. Xiaoqian, 2010, 'Stalemate of participation: participatory village development planning for poverty alleviation in China', in N. Long, Y. Jingzhong, and W. Yihuan, eds, Rural Transformations and Development-China in Context: The Everyday Lives of Policies and People, Cheltenham, UK: Edward Elgar Editions, pp. 312-326. 